\title{
Homorganic Nasal Assimilation in Arsi-Bale Afan Oromo: A Non-Linear Phonology
}

\author{
Tilahun Negash \\ College of Social Sciences and Humanities, Debre Markos University, Debre Markos, Ethiopia
}

Email address:

tntilingp@gmail.com

To cite this article:

Tilahun Negash. Homorganic Nasal Assimilation in Arsi-Bale Afan Oromo: A Non-Linear Phonology. Humanities and Social Sciences. Vol. 3, No. 4, 2014, pp. 240-248. doi: 10.11648/j.hss.20150304.13

\begin{abstract}
This paper is entitled: "Homorganic nasal assimilation in Arsi-Bale Afan Oromo: A non linear Approach". The paper is limited to nasal assimilation found in one of the Afan oromo (AO) dialects spoken in Ethiopia. The dialect is a member of the AO language cluster, which belongs to East-Cushitic branch of Afro-Asiatic super family. The study attempts to use Feature Geometry branched from the theory of Autosegmental Phonology proposed by Goldsmith (1976). The paper is basically based on the fieldwork in Arsi, one of the Zones in Oromia Regional State of Ethiopia. The data were gathered from five native speakers of Arsi-Bale Afan Oromo (ABAO) who were born in Arsi regional state of Ethiopia. The informants were made to gather those words and sentences that contain nasal sounds. They were made to repeat the words and sentences several times in different order and the data were recorded by using an audio tape recorder for analysis. Then, the pronunciations were transcribed phonemically and phonetically using the IPA conventions as revised to 2005. The results show that the $/ \mathrm{n} /$ in emphatic prefix $\{$ hin- $\}$ and word internally undergoes partial and total assimilation. When the alveolar $/ \mathrm{n} /$ in the prefix boundary or word internally is followed by a word with initial stops $/ \mathrm{b} /, / \mathrm{m} /, / \mathrm{g} /, \mathrm{k} /$ ejective $/ \mathrm{k}^{\prime} /$, fricative $/ \mathrm{f} /$, and liquids $/ 1 /, / \mathrm{r} /$, the partial homorganic nasal assimilation occurs and the nasal $/ \mathrm{n} /$ totally assimilates to the semi-vowels $/ \mathrm{w} /$ and $/ \mathrm{j} /$.
\end{abstract}

Keywords: Afan Oromo, Assimilation, Feature Geometry, Autosegmental Phonology

\section{Introduction}

The Oromo live over a huge area stretching from Somalia through north eastern Ethiopia to Kenya and the majority of them live in Ethiopia (Campbell and King, 2013). Oromo represent the largest ethnic group both numerically and geographically among all the ethnic groups that live within the boundary of Ethiopia (Gragg 1976, Heine 1981). Oromíffáa, or the Oromo language is the modern term used in Ethiopia for the language spoken by the Oromo. In the $19^{\text {th }}$ and most of the $20^{\text {th }}$ century, it was usually referred to by its speakers as afáan Oromóo 'language of the Oromo' or as afáan Órmáa 'language of the people' or 'language of the Orma' (Banti, 2008). The elder speakers of Arsi-Bale dialect confirm the speakers' preference of the term Oromo and Afan Oromo when referring to themselves and the language respectively (personal communication). Hence, this paper uses the terms accordingly to accommodate the preference of the language speakers.

The summary and statistical report of the 2007
Population and Housing Census of Ethiopia which was published in December 2008 and was comprised of the 1984 and 1994 information about the people of Ethiopia in addition to the 2007 facts on the inhabitants. The 1994 Population and Housing Census of Ethiopia for example, demonstrated that the population size of Oromo was $17,080,318(32.1 \%)$ out of the $53,477,265$ total population of Ethiopia. According to the 2007 population and Housing Census, this number has increased by $2.4 \%$ over the past ten years to become $25,488,344$ which accounts for $(34.5 \%)$ of the 73,918,505 total population of Ethiopia. The following map shows the distribution of Afan Oromo speakers in Ethiopia. 




Map 1. Map of Afan Oromo speaking area

One group of Afan Oromo speakers is the Arsi Oromo people. The Arsi are one of the many branches of the Oromo people who predominantly live in the Arsi and Bale regions of the Oromia Regional State in Southern Ethiopia. Based on the 2007 census conducted by the Ethiopian Central Statistical Agency (ECSA), the population of Arsi stood at $2,637,657$, of which $1,323,424$ were men and $1,314,233$ were women; in an area of 19,825.22 square kilometers. "The people of Arsi claim to have descended from a single individual called Arsse; the name of a person who is believed to have been the "founding father" of the group" (Mindaye 2005: 18). "The two main branches of Arsi Oromo are Mandoo and Siqqo. Mandoo refers to the Arsis in the Arsi and northern Bale Zones, while Siqqo refers to those mainly in the Bale Zone" (Jeyilan: 2005). As the famous tradition of this group of Afan Oromo speakers further explains, Arsse had two sons whose names were Mando (Mandayou) and Siqqo (Siqqisa), Mando was the younger son (quxusu) of Arsse while siqqo was the elder (angafa) (Mindaye: 2005). "Besides the provinces of Arsi and Bale which Arsis overwhelmingly occupied, one also finds a significant proportion of the Arsi Oromo in neighboring provinces of Showa and Sidamo" (Mindaye 2005: 18). The Arsi are divided into the Mando and the Siqqo moieties. The Siqqo are composed of five submoieties collectively called Shanan siqqo (the five related to Siqqo). They are: Bullallaa, Wacaalee, Jaawii, Waajii and Ilaannii. The Mando are composed of seven sub-moieties collectively called Torban mando (the seven ones of Mando). They are: Raayyaa, Kajawaa, Hawaxaa (Hawaxxuu), Utaa, Waayyuu, Harawaa and Biltuu (Jeyilan 2005: 26). These people speak the same dialect of Afan Oromo and share the same culture and traditions. The Arsi have developed a concept of Arsoma, which is roughly translated as "Arsihood" in English. The kinship in the Arsi Oromo society is hierarchically structured into five categories that range from micro- to macro-kinship orders. The categories exist as: Mana, Warra, Aanaa, Balbala and Gosa (Mindaye: 2005). Gosa is the largest kinship unit in the scenario of kinship organization of the Arsi Oromo people as shown in the following diagram.

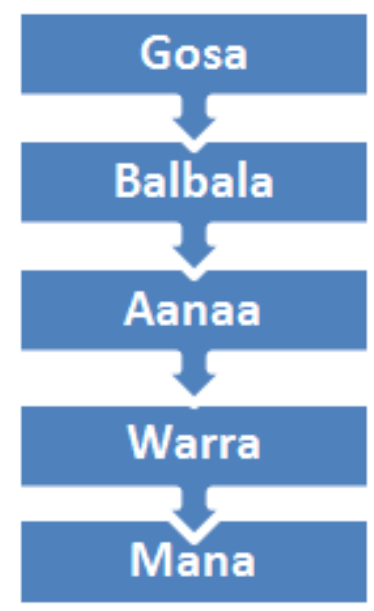

Diagram 1. The scenario of kinship organization of Oromo people

\section{Dialects of Afan Oromo}

Classifications of Oromo dialects is inconsistent It has from 3 to 8 dialects. Bender and Mulugeta (1976: 1-2), have classified Afan Oromo in to eight dialect These are: Mecca (Western), Tulama (Central), Wallo and Rayya (Northern), Arusi, Guji and Borena (Southern) and Hararge (Eastern). Although the base for the classification is not stated clearly in the study, it appears to be a geographical location.

Heine (1981: 15), recognizes two major dialect areas, “Central Afan Oromo' and 'Tana Afan Oromo." Gragg (1982: 12-13) further wrote on the dialect areas of the Afan Oromo spoken in Ethiopia. He states that Afan Oromo could be classified into four dialect areas, namely: Western (Wallagga, Iluu Abbaa Bora, Jimma), Central (Shawaa), Eastern (Hararge) and Southern (Arsii-Baale, Gujii and Boorana). Kebede (1991) has classified Afan Oromo (including that of Kenya) into four dialect areas depending on phonological bases. These are: North Western (Tulma, Mecca), Eastern (Harar, Arsi-Bale, Wallo, Rayya), Central (Arsi-Zeway, Guji, Borana, Munyo, Orma), and Southern (Waata). In a study by Lloret (1994: 6), the various dialects of Afan Oromo are divided along a western and eastern axis. The western dialect encompasses Raayyaa, Baate, Macca, and Tuulama while the eastern dialect is comprised of Harar, Arsi, Boorana, Gabra, Orma, and Waata. Kebede (2005), on the other hand, suggests that Afan Oromo can be sub-divided into five major dialect areas: (1) Waata, Orma, Borana of Ethiopia and Kenya, and Arsi, (2) Tuulama and Mecca, (3) Raya, (4) Hararge, and (5) Baate. Banti (2008). In this study, the primary dialect groups of Afan Oromo are classified as: (1) Northern Afan Oromo (Baate and Raayyaa), (2) Western Afan Oromo (Mecca), (3) Highland Shawan Afan Oromo (Tuulama), (4) Eastern Afan Oromo (Hararge), (5) Central Afan Oromo (Gujii and Arsii), and (6) Southern Afan Oromo (Boorana). Kebede (2009) conducted extensive research on Oromo dialects as part of his doctoral study based on morphophonemic and phonetic-lexical data, he constructed a genetic tree of Oromo dialects, whereby the dialects were divided into ten genetic groups such as western, eastern, 
central, south-east-north, Waata, northeast east, north, Wollo and Raya. The most recent work on the classification of Afan Oromo dialect is Feda (2015). He argues that the proposal of new classification of Oromo dialects is required due to three major reason. These are: 1 . the previous classifications were done based on subjective comparisons of mainly lexical differences. 2. the past classifications produced inconsistent results causing confusions to readers. 3 . in the old classifications, the labels that are used to identify the dialects are not inappropriate as the names of Oromo subgroups such as Macha and Tulama have been used to refer to the western and the central varieties but names of geographical areas have been used to identify the other varieties. In his classification, the Oromo language have been divided into five dialects such as west, central, northern, southern, southeast and eastern dialects as indicated in the following tree-diagram.

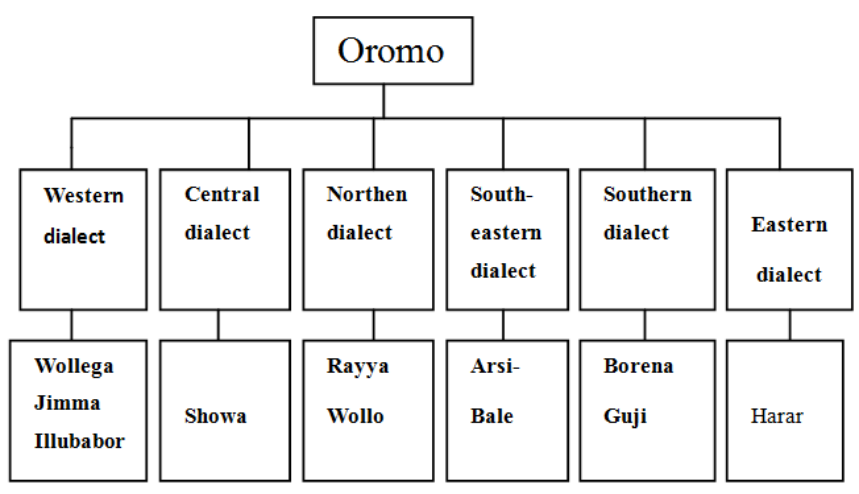

Diagram 2. Classification of Afan Oromo dialects. Feda (2015).

As one can perceive from the above recent and reasonable classification of Afan Oromo into its respective dialect areas, he/she can identify that one particular dialect of Afan Oromo is the southern eastern dialect that comprises of Arsi-Bale Afan Oromo which is spoken by the people of Arsi who inhabit both in Arsi and Bale Zones of Oromia regional state. Thus, this dialect may differ in structural levels from other dialects mentioned above.

There is, in fact, notably large number of linguistic study on Afan Oromo language by Ethiopians as well as foreigners; however, most of them are descriptive works and they are not fully comprehensive. Moreover, there is limited study on Afan Oromo phonology and more importantly, the Arsi-Bale Oromo phonology has not been described yet. Afan Oromo is one of the regional languages of Ethiopia. It is the trade language of Ethiopia and is used as a lingua franca in Ethiopia, Somalia, and Kenya. Afan Oromo is used in regional governmental administration, national commerce, and in mass media (newspaper, television, radio). For Afan Oromo achieved the status of literary language of Ethiopia in 1992, it is used as the medium of instruction in grades 1-8 and is taught in both secondary schools and in institutions of higher education in Oromia region. Hence, the study of its grammar deserves great attention. There are aspects of the grammar, such as the sound system that need detailed study in the light of recent developments in theoretical linguistics. Regarding the need and opportunity for research on Arsi-Bale Afan Oromo (Abbas, 1991: 50-84), cited in journal of Oromo studies, emphasizes that "The groups of Arsi, Bale and Karrayyu have been relatively less studied by social scientists and there is a great need for researches on these groups for there are ample opportunities for research among these people.' This seeks the attention of linguists and the writer of this paper is initiated to represent the phonology of this dialect. According to the researcher, to explore the characteristic feature of the language under question, examining it with the current theories may be more comprehensive. This research, therefore, attempts to explore the phonological phenomena of Arsi-Bale dialect Afan Oromo from a theoretical perspective and it considers Autosegmental approach of Goldsmith $(1976,1990)$ as a framework. This is because the theory addresses analytical issues that the SPE (Sound Pattern of English) couldn't handle. The study will center on the representation of the phonological phenomena of Arsi-Bale dialect in the light of Autosegmental phonology.

The paper specifically attempts to explore the homorganic nasal assimilation of Arsi-Bale dialect Afan Oromo from a theoretical perspective and is guided by the Autosegmental approach of Goldsmith $(1976,1990)$ and the Feature Geometry of Clements (1985).

\section{Assimilation as Spreading of Features}

A phonological process by which one segment, the target, takes on a feature or a set of features of another segment (i.e, the trigger), within a specified domain is referred to as assimilation. The vast majority of languages assimilation processes obtain between strictly adjacent segments, but some languages display long distance assimilatory effects. According to Youssef (2013: 23), phonetically, local assimilation may be attributed to the minimization of articulatory effort (i.e. to avoid unnecessary shifts in stricture or place of articulation within a sequence of segments). Assimilation includes partial absorption in which case one consonant becomes more similar, but not identical to a neighboring consonant and total assimilation in which case the adjacent sounds become identical forming false geminate; consecutive consonants occurring one after the other.

Recent research in phonology reveals that a segment is not just an unorganized bundle of features, but also that features possess their own internal organization. This is well reflected in Feature Geometry theory proposed by many researchers including Clements (1985), Sagey (1986), Halle (1989), and McCarthy (1988). One standard analysis of assimilation in Autosegmental phonology is autosegmental spreading. In Autosegmental phonology, (Goldsmith 1976, 1990; Clements 1985), features are represented as autosegments that may be associated with nodes. The representations are non-linear in which the 
highest mother-node establishes linearity across segments. The fact that partial assimilation treats certain groups of features as a sub-matrix is captured by the featureGeometry framework in which the features are grouped into larger tiers called class tiers. These class tiers are in turn organized under the root node. The root node represents the phonological unity of the features that form together a phonological segment. It is annotated with the binary feature [consonant] and [sonorant], the so called major class features that divide the segments of a language into three classes are: [+cons, -son.] obstruents, [+cons, +son.] sonorant consonants and [-cons, +son.] vowels. Clements recognizes three major groups of features; laryngeal, manner and place features. He refers to these as "Class Nodes." Clements also assumes that the Manner Node and Place Node combine to make another internal hierarchical group: the "Supralaryngeal Node." Clements uses the term "tier" to refer to the internal structural unit. Two tiers constitute a plane on which phonological rules can be expressed as changes in association with lines.

Regarding the Feature Geometry model (Kebede 1994: 9) states that the theory is a recent development stemming from Autosegmental phonology. Citing Pullyblank (1988) and Paradis and Prunit (1991), Kebede explains that distinctive features are organized into natural classes that make up sets. These sets of features are represented by means of hierarchical trees called Feature Geometry. Each feature and each node of the feature in the tree constituents is a possible locus for a phonological rule. The Feature Geometry proposed by Clements (1985) can be summarized as follows.

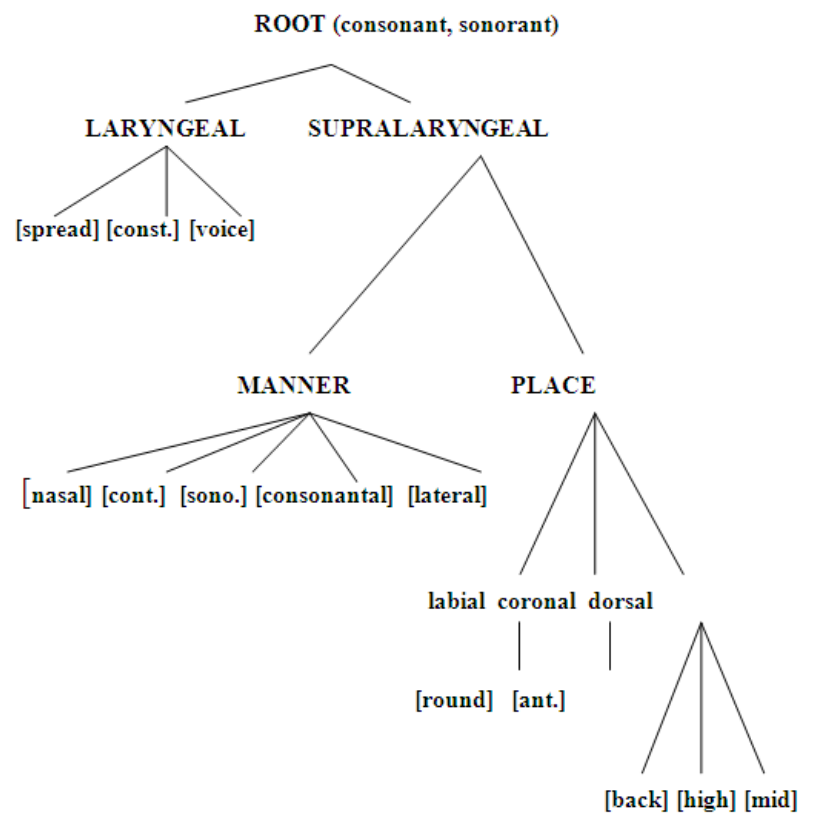

Figure 1. Feature Geometry proposed by Clements (1985)

In nonlinear approaches to phonology such as Autosegmental Phonology or Feature Geometry, assimilation occurs when a distinctive feature (or subset of features) within a segment changes to agree with the feature(s) of an adjacent segment. This is achieved through linking and the de-linking of features (Clements, 1985; Goldsmith, 1976; McCarthy, 1988). In other words, in Autosegmental phonology, assimilation is associating or linking a spreading feature with a target root node. This process is also termed "feature spreading" whereby a feature spreads from a trigger to a target.
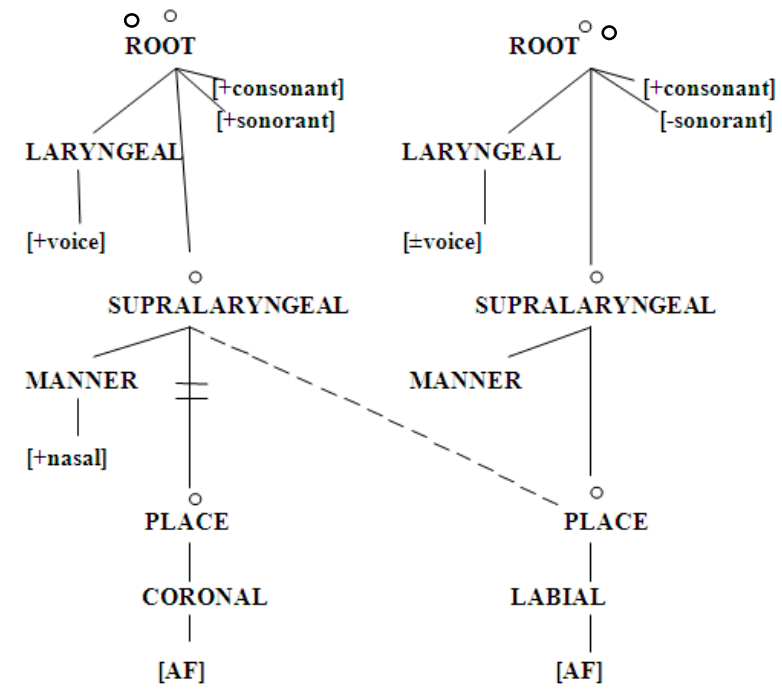

Figure 2. Spreading of labial feature to the coronal.

It is crucial to analyze assimilation via Autosegmental modeling because of the advantages that this process has over linear modeling. Features associate independent of the skeletal tier in the Autosegmental model. This is one of the critical advantages of the Autosegmental model in analyzing assimilation over other models. In the Autosegmental model of analysis, assimilation rules can be represented as spreading of some feature over skeletal slots. Based on the framework of Feature Geometry model by Clements (1985), the delinking line goes from the articulation node (PL) on the right side and moves backwards. The rule of assimilation in which features spread the distinctive features from the Place of articulation node (PL) on the right side backwards to the supralaryngeal (SL) node on the left side can be represented with the Feature Geometry model proposed by Clements (1985) as follows:

In Arsi - Bale Afan Oromo, assimilation occurs where a segment becomes phonetically more similar to an influencing segment. This Dialect of Afan Oromo exhibits three types of assimilations. They may be referred to as place, manner, and total assimilation.

\section{Nasal Place Assimilation}

In many languages, nasal consonants are homorganic with a following obstruent. This process is probably the most common phonological process in languages around the world (Al-Shuaibi 2011). It is a phonological process where a nasal phone (/n/ in Arsi-Bale Afan Oromo case) assimilates in place to the immediately following consonant. The 
assimilation can be both partial and total. Homorganic nasal assimilation takes place in different environments in ArsiBale Afan Oromo. It occurs after $/ \mathrm{n} /$ within the morpheme or when the emphatic marker prefix /hin/ is followed by 1) stop sounds $/ \mathrm{b}, \mathrm{m}, \mathrm{k}, \mathrm{g} / 2$ ) ejective sound $/ \mathrm{k}^{\prime} / 3$ ) fricative $/ \mathrm{f} / \mathrm{4}$ ) liquids $/ 1, \mathrm{r} /$ and 5) semi-vowels $/ \mathrm{w}, \mathrm{j} /$. The assimilation is partial for the stop sound under 1 , an ejective sound under 2 , and a fricative sound under 3 where they share the place of articulation and liquids under 4 share manner of articulation. The following example words from a-h are comprised of words with partial assimilation of the nasal phone $/ \mathrm{n} /$ to their respective phones.

a) Prefix boundary + word with initial $/ \mathrm{b} /$

\begin{tabular}{|c|c|c|}
\hline Underlying form & Output & Meaning \\
\hline /hin + beeka/ & [hímbèekà] & 'he knows' \\
\hline /hin + barbaada/ & [hímbàrbàadà] & 'he wants' \\
\hline at/hın + booja/ & [hímbòojà] & 'he cries' \\
\hline /hın + bara/ & [hímbàrà] & 'he learns' \\
\hline /hin + barooda/ & [hímbàròodà] & 'It bellows \\
\hline \multicolumn{3}{|c|}{ b) Prefix boundary + word with initial $/ \mathrm{m} /$} \\
\hline /hin + morma/ & [hímmòrmà] & 'he protests' \\
\hline /hin + mul?ata/ & [hímmùl?àtà] & 'it is seen' \\
\hline /hin + mooja/ & [hímmòojà] & 'he wins' \\
\hline$/ \mathrm{hin}+$ mura/ & [hímmùrà] & 'it cuts' \\
\hline$/ \mathrm{h} t \mathrm{n}+\mathrm{mi}$ ?awa/ & [hímmì?àwà] & 'it tastes goo \\
\hline
\end{tabular}

c) Prefix boundary + word with initial $/ \mathrm{k} /$

$\begin{array}{lll}\text { /hın + kaasa/ } & \text { [hínkàasà] } & \text { 'he picks' } \\ / \text { hın + kuusa/ } & \text { [hínkùusà] } & \text { 'he stores' } \\ / \text { hın + kabala/ } & \text { [hínkàbàlà] } & \text { 'he slaps' } \\ / \text { hın + kolfa/ } & \text { [hínkòlfà] } & \text { 'he laughs' } \\ / \text { hın + kunnuunsa/ } & \text { [hínkùnnùunsà] } & \text { 'he treats' } \\ \text { d) Prefix boundary + word with initial /g/ } & \end{array}$

$\begin{array}{lll}/ \text { hın }+ \text { guba/ } & \text { [híngùbà] } & \text { 'he burns' } \\ / \text { hin }+ \text { guddata/ } & \text { [híngùdàtà] } & \text { 'he grows' } \\ / \text { hin }+ \text { gala/ } & \text { [híngàlà] } & \text { 'he enters' } \\ / \text { hin }+ \text { goga/ } & \text { [híngògà] } & \text { 'it dries' } \\ / \text { hin }+ \text { gurgura/ } & \text { [híngùgùrà] } & \text { 'he sells' }\end{array}$

e) Prefix boundary + word with initial $/ \mathrm{k}$ '/

\begin{tabular}{|c|c|c|}
\hline$/ \mathrm{h} ı \mathrm{n}+\mathrm{k}$ 'aba/ & [hínk’àbà] & 'he owns' \\
\hline /hın + k'aak'a/ & [hínk'àak'à] & 'he talks' \\
\hline /hın + k'ooda/ & [hínk'òodà] & 'he divides' \\
\hline /hın + k'ala/ & [hínk'àlà] & 'he slaughters' \\
\hline$/$ hin + k'ara/ & [hínk'àrà] & 'he sharpens' \\
\hline
\end{tabular}

f) Prefix boundary + word with initial / f / /hın + fajja/ [hímfàjjà] 'he will be healed'

$\begin{array}{lll}/ \text { hın }+ \text { foojja?a/ } & \text { [hímfòojjà?à] } & \text { 'it will be better' } \\ / \text { hın }+ \text { faallessa/ } & \text { [hímfàallèssà] } & \text { 'it disorders } \\ / \text { hın }+ \text { fe?a/ } & \text { [hímfè?à] } & \text { 'he needs' } \\ / \text { hın }+ \text { funaana/ } & \text { [hímfùnàanà] } & \text { 'it gathers' }\end{array}$

g) Prefix boundary + word with initial /1/

\begin{tabular}{|c|c|c|}
\hline$/$ hin $+/$ laala/ & [híllàalà] & 'he sees' \\
\hline /hin + /lalaafa/ & [híllàlàafa] & 'it softens' \\
\hline$/$ hin + lola/ & [híllòlà] & 'he quarrels \\
\hline /hin + lit'a/ & [híllit'à] & 'he goes' \\
\hline /hın + lakaaja/ & [hílàkkàajà] & 'he counts' \\
\hline h)Prefix boun & $y+$ word with & \\
\hline$/ \mathrm{h} \mathrm{in}+\mathrm{rafa} /$ & [hírràfà] & 'he sleeps' \\
\hline$/ \mathrm{h} t n+$ raasa/ & [hírràasà] & 'he jerks' \\
\hline /hin + rip'a/ & [hírrìp'à] & 'he ignores' \\
\hline$/ \mathrm{hin}+$ rooba/ & [hírròobà] & 'it rains' \\
\hline in + rarraasa/ & [hírràrràasà] & 'he hangs \\
\hline
\end{tabular}

Based on the framework of Feature Geometry model by Clements (1985), the delinking line goes from the place of articulation node (PL) on the right side backwards to the supralaryngeal (SL) node on the left side and simultaneously spreads its distinctive features. In line with Clement's proposal, homorganic nasal assimilation in Arsi-Bale Afan Oromo operates from the place of articulation node (PL) on the right side leftwards to the supralaryngeal (SL) node on the left side and simultaneously spreads its distinctive features. This phonological process occurs at the prefix boundary, as in the examples under a-h above and within the domain of morpheme as in \{hanba\} [hámbà] 'left over'. \{dangaa\} [dángáa] 'territory', \{sink'ee\} [sínk'ée] 'stick' \{hanfala\} [hámfálá] 'sash'. Based on the generalizations and the illustrative examples of the phonological process of homorganic nasal assimilation in Arsi-Bale Afan Oromo, the situations of this process are as follows:
a. $/ \mathrm{nb} / \rightarrow[\mathrm{mb}]$
b. $/ \mathrm{nm} / \rightarrow[\mathrm{mm}]$
c. $/ \mathrm{nk} / \rightarrow[\mathrm{yk}]$
d. $/ \mathrm{ng} / \rightarrow[\mathrm{ng}]$
e. $/ \mathrm{nk}^{\prime} / \rightarrow\left[\mathrm{yk}^{\prime}\right]$
f. $/ \mathrm{nf} / \rightarrow[\mathrm{mf}]$
g. $/ \mathrm{nl} / \rightarrow[11]$
h. $/ \mathrm{nr} / \rightarrow[\mathrm{rr}]$

As can be observed from the examples above, the coronal $/ \mathrm{n} /$ undergoes the process of assimilation when it combines with an underlying word at initial position or in morphemes where phonemes namely: /b/, /m/, /g/, /k/, /k'/, /f/, /1/, and /r/ occur after $/ \mathrm{n} /$. In other words, when the alveolar $/ \mathrm{n} /$ in the prefix boundary within morpheme is followed by a word with initial stops $/ \mathrm{b} /, / \mathrm{m} /, / \mathrm{g} /, / \mathrm{k} /$ ejective $/ \mathrm{k}$ '/, fricative $/ \mathrm{f} /$, and liquids $/ 1 /, / r /$, the partial homorganic nasal assimilation occurs in Arsi-Bale Afan Oromo as clearly shown in the examples presented above in a-h. 
Taking Clements (1985) feature model into account, the assimilation of the nasal phone into the following phone in Arsi-Bale Afan Oromo can be depicted pictorially. The following figures show the process of delinking of the nasality and spreading of certain features back to the nasal phone. The following figures indicate the representations of nasals into their respective phones.

\section{Place of Articulation Assimilation}

The figure below illustrates the process of delinking the nasal coronal $/ \mathrm{n} /$ from its distinctive feature. Accordingly, the assimilation process consists of spreading the labial (LABIAL) feature linked to the labial $/ \mathrm{b} /$ leftwards to the nasal coronal $/ \mathrm{n} /$, and simultaneously delinking the coronal feature of the nasal coronal $/ \mathrm{n} /$ from its own place of articulation.



\section{CORONAL LABIAL}

Figure 3. The process of delinking the coronal feature $/ n /$

After the delinking of the nasal coronal $/ \mathrm{n} /$ from its distinctive feature, the nasal coronal $/ \mathrm{n} /$ acquires the distinctive features of the labial $/ \mathrm{b} /$. This happens after the process of spreading and $/ \mathrm{n} /$ is realized as a nasal labial $/ \mathrm{m} /$ as is depicted in the following figure.



LABLAL

Figure 4. The output of the nasal assimilation of $/ \mathrm{nb} /$

Similar to the spreading of the place feature of $/ \mathrm{b} /$ to the $/ \mathrm{n} /$ leftwards, the feature of $/ \mathrm{m} /$ spreads to the $/ \mathrm{n} /$ phone to be pronounced as $/ \mathrm{m} /$ as shown in figure 5 .

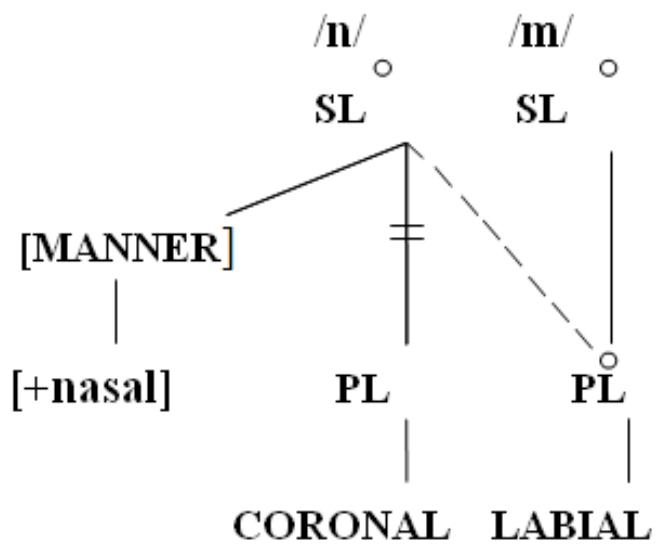

Figure 5. The process of delinking the coronal feature $/ n /$

Due to the spreading of the labial feature to the left, the alveolar nasal $/ \mathrm{n} /$ sound changes its place feature to bilabial and thus, is pronounced as $/ \mathrm{m} /$.

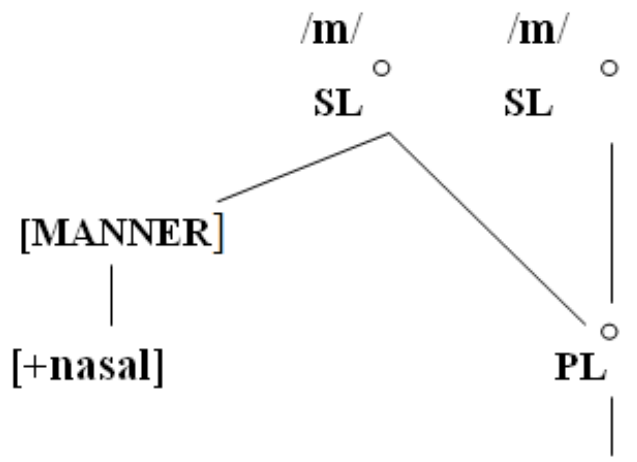

LABIAL

Figure 6. The output of the nasal assimilation of $/ \mathrm{nm} /$

The coronal nasal /n/ assimilates to dorsal phones as well. Figure 7 illustrates the process of delinking of the nasal coronal $/ \mathrm{n} /$ and spreading of the dorsal (DORSAL) feature from $/ \mathrm{k} /$ to the nasal coronal $/ \mathrm{n} /$.



Figure 7. The process of delinking the coronal feature $/ \mathrm{n} /$

After gaining the dorsal feature from the following dorsal sound $/ \mathrm{k} /$, the nasal coronal $/ \mathrm{n} /$ is articulated as the nasal dorsal $/ \mathrm{y} /$, which has the same place of articulation as the 
phoneme $/ \mathrm{k} /$. This is illustrated in figure 8 .

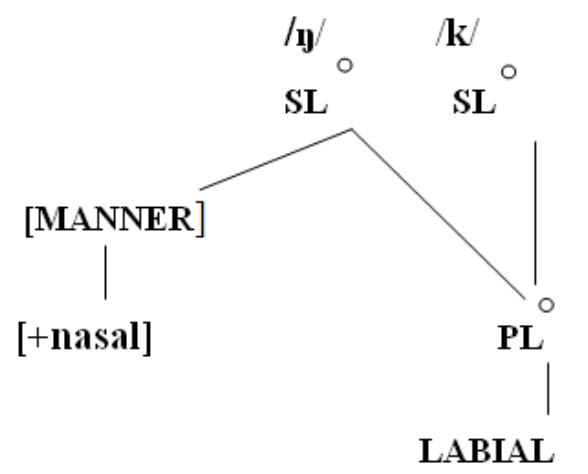

Figure 8. The output of the nasal assimilation of $/ \mathrm{nk} /$

Figure 9 presents the process of delinking the coronal $/ \mathrm{n} /$ from its place feature. As shown, it consists of spreading the dorsal (DORSAL) feature linked to the velar /g/ leftwards to the nasal coronal $/ \mathrm{n} /$ and the simultaneous delinking of the coronal feature of the nasal $/ \mathrm{n} /$ from its own place feature. Therefore, the nasal coronal $/ \mathrm{n} /$ is articulated as the nasal dorsal $/ \mathrm{y} /$, which has the same place of articulation as the dorsal $/ \mathrm{g} /$.

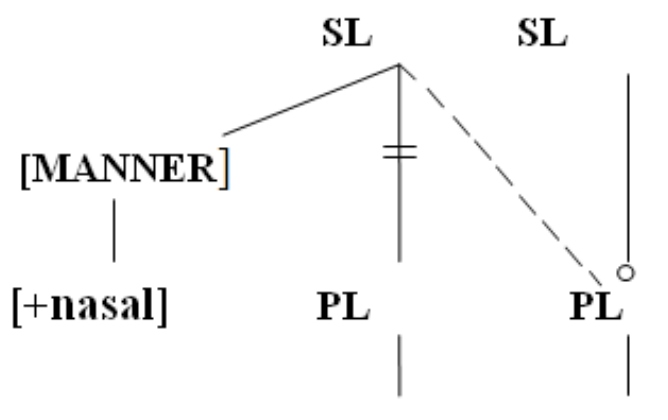

\section{CORONAL DORSAL}

Figure 9. The process of delinking the coronal feature /n/



Figure 10. The output of the nasal assimilation of /ng/

Figure 10 shows that the nasal coronal $/ \mathrm{n} /$ acquired the distinctive features of the dorsal $/ \mathrm{g} /$ after the process of spreading to be articulated as the nasal dorsal $/ \mathrm{y} /$.

Figure 11 illustrates the process of delinking the coronal feature. The assimilation process consists of spreading the dorsal (DORSAL) feature linked to the dorsal $/ \mathrm{k} /$ leftwards to the nasal coronal $/ \mathrm{n} /$, and the simultaneous delinking of the coronal $/ \mathrm{n} /$ from its own place of articulation.



CORONAL DORSAL

Figure 11. The process of delinking the coronal feature $/ n /$

Figure 12 shows that the nasal coronal $/ \mathrm{n} /$ is realized as the nasal dorsal $/ \mathrm{y} /$, which has the same place of articulation as the dorsal $/ \mathrm{k} \%$.

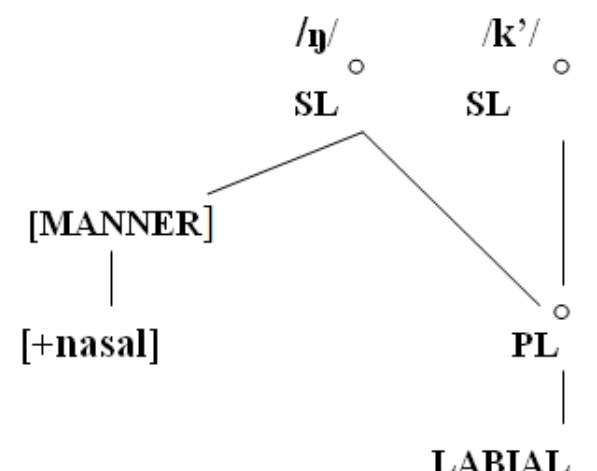

Figure 12. The output of the nasal assimilation of $/ n k$ '/

\section{Manner of Articulation Assimilation}

So far we have discussed the assimilation of the place feature to the nasal $/ \mathrm{n} /$. There are also situations where the assimilation of manner of articulation takes place. This is evidenced through the example words under $\mathrm{g}$ and $\mathrm{h}$ above where the lateral $/ \mathrm{l} /$ and the trill $/ \mathrm{r} /$ spread their feature leftwards to the coronal /n/ as in /hin + /laala/ [híllàalà] "he sees" and /hın + raasa/ [hírràasà] "he jerks" respectively.



Figure 13. The process of delinking the nasal feature from $/ \mathrm{n} /$

The partial assimilation undertaken can be represented 
through Feature Geometry, as in figure 13.

After the nasal feature is delinked from the sound/n/, the sound gains the manner feature from the coronal sound/1/ and is pronounced the same way as $/ 1 /$ due to the fact that both are identical in place feature.



Figure 14. The output of the nasal assimilation of $/ \mathrm{nl} /$

The other homorganic nasal assimilation, which is partial, can be noted where the coronal $/ \mathrm{n} /$ sound assumes the feature of the sonorant sound $/ \mathrm{r} /$. In this case, the sonorant spreads its feature to the preceding nasal sound. This process is represented in figure 15 .

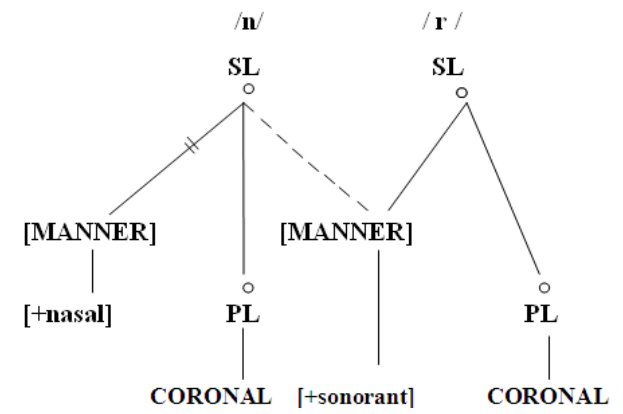

Figure 15. The process of delinking the nasal feature from $/ \mathrm{n} /$



Figure 16. The output of the nasal assimilation of $/ \mathrm{nr} /$

After spreading the sonorant sound leftwards to the nasal sound, the nasality of a sound disappears and is replaced by sonority because the realization differs in manner of articulation. Thus, the coronal $/ \mathrm{n} /$ is realized as $/ \mathrm{r} /$ as shown in figure 16 .

\section{Total Assimilation}

In addition to the partial homorganic assimilation exemplified under $\mathrm{a}-\mathrm{h}$, the coronal $/ \mathrm{n} /$ undergoes the total assimilation in Arsi-Bale Afan Oromo. This happens when $/ \mathrm{n} /$ is followed by semi-vowels. The words grouped under $\mathrm{i}$ and $\mathrm{j}$ below are example words for the assimilation of $/ \mathrm{n} /$ to semi-vowels.

i) Prefix boundary + word with initial /w/

\begin{tabular}{|c|c|c|}
\hline$/ \mathrm{h} 1 \mathrm{n}+$ waada/ & [híwwàadà] & "he roasts" \\
\hline /hın + waraaba/ & [híwwàràabà] & "he fetches" \\
\hline /hin + wakeefata/ & [híwwàk’èefàtà] & "he worships" \\
\hline /hın + waama/ & [híwwàamà] & "he calls" \\
\hline /hin + warana/ & [híwwàrànà] & "he stabs" \\
\hline \multicolumn{3}{|c|}{ j) Prefix boundary + word with initial $/ \mathrm{j} /$} \\
\hline /hin + jaasa/ & [híjjàasà] & "he drives out" \\
\hline /hin + juusa/ & [híjjùusà] & "it laughs (hyena)" \\
\hline /hın + jaada/ & ]híjjàadà] & "he thinks" \\
\hline$/ \mathrm{h}$ n + jaala/ & [híjjàalà] & "he tries" \\
\hline /hın+jaap'ata/ & [híjjàap'àtà] & "he mounts" \\
\hline
\end{tabular}

The generalizations and the illustrative examples of the phonological process of homorganic nasal assimilation in Arsi-Bale Afan Oromo were indicated under i-viii. There is also another circumstance of the assimilation process that is based on total assimilation. This process can be stated accordingly:

a. $/ \mathrm{nw} / \rightarrow[\mathrm{ww}]$

b. $/ \mathrm{nj} / \rightarrow[\mathrm{jj}]$

As depicted in (i) and (ii), the semi vowels spread their place and manner feature to the coronal sound $/ \mathrm{n} /$. This process can be represented through Feature Geometry as in figure 17 .

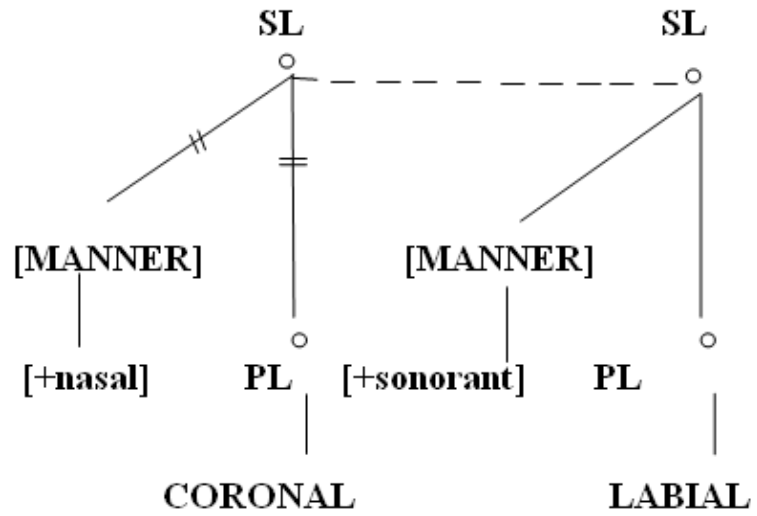

Figure 17. The process of delinking of the nasal and coronal features from /n/

Due to the total assimilation of the $/ \mathrm{n} /$ phone to the semivowels $/ \mathrm{w} /$ and $/ \mathrm{j} /$, the representational figure becomes comprised of identical structures for both sounds after the spreading of the place and manner feature to the left as the 
following feature illustrates.

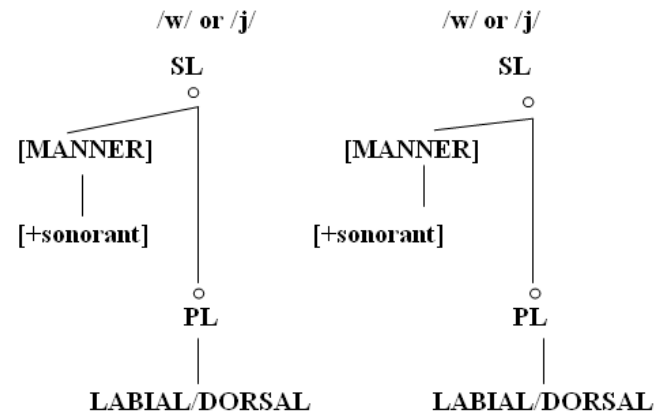

Figure 18. The output of the delinking of the nasal and coronal features from $/ n /$.

\section{Conclusion}

The paper explores one aspect of phonological phenomena of Arsi-Bale Afan Oromo considering Autosegmental phonology of Goldsmith $(1976,1990)$ as a framework. It explains how the nasal sound $/ \mathrm{n} /$ assimilates to the following consonant sounds for it is an active ingredient that assimilates to the following sounds in Arsi-Bale Afan Oromo.

The data depicts that in Arsi-Bale Afan Oromo, homorganic nasal assimilation takes place within morpheme after the nasal sound $/ \mathrm{n} /$ and across morpheme boundary when the emphatic marker prefix $/ \mathrm{htn} /$ is followed by stop sounds $/ \mathrm{b}, \mathrm{m}, \mathrm{k}, \mathrm{g} /$ ejective sound $/ \mathrm{k}$ / fricative $/ \mathrm{f} /$, liquids $/ \mathrm{l}$, $\mathrm{r} /$ and semi-vowels $/ \mathrm{w}, \mathrm{j} /$. The assimilation is partial when $/ \mathrm{n} /$ is followed by the stops, the ejective, and the fricative. These sounds share the place of articulation to the nasal sound $/ \mathrm{n} /$ in the assimilatory process. The liquids share only manner of articulation with the nasal sound $/ \mathrm{n} /$ for they basically have identical place feature with $/ \mathrm{n} /$. The nasal $/ \mathrm{n} /$ totally assimilates to the semi-vowels $/ \mathrm{w} /$ and $/ \mathrm{j} /$. All the assimilatory processes are clearly represented by the Feature Geometry of Clements (1985). The researcher practiced the theory on homorganic nasal assimilation of Arsi-Bale Afan Oromo and confirmed that it is accurate in representing the process. He suggests that it is possible to use this theory to represent other phonological processes as well.

\section{References}

[1] Al-Shuaibi A. 2011. Nasal Homorganic Assimilation Phenomenon in YTD: An Autosegmental Analysis. In Strength for Today and Bright Hope for Tomorrow. V. 11

[2] Bender, M.L. Mulugeta Etaffa and Stinson, D.L. 1976. In Bender et al (eds) Language in Ethiopia . London: Oxford University Press.

[3] Banti, G. (2008). "Oromiffaa". In S. Uhlig (ed.). Encyclopaedia Aethiopica, ,Wiesbaden:Otto Harrassowitz.

[4] Clements, George N. (1985). The Geometry of Phonological Features, Phonology 2: 225-252.
[5] Campbell , George L. and King , Gareth. (2013). Compendium of the World's Languages. USA. Third Edition. V.I

[6] Feda, Negese. (2015). Classification of Oromo Dialects: A Computational Approach. International Journal of Computational Linguistics (IJCL), Volume (6) : Issue (1) : 2015

[7] Federal Democratic Republic of Ethiopia Population Census Commission. 2008. Summary and Statistical Report of the 2007 population and Housing census. Addis Ababa.

[8] Goldsmith, John A. 1976. Autosegmental Phonology. Ph.D Thesis. MIT.

[9] Goldsmith, John A. 1990. Autosegmental and Metrical Phonology. Cambridge, Blackwell.

[10] Gragg, G. 1976. Oromo of Wallaga. In Bender, M.L. et al (ed). The Non-Semitic Languages of Ethiopia. East Lansing: Africa Studies Center. Michigan: Michigan State University Press. PP. 166-195

[11] Gragg, G. 1982. Oromo Dictionary, Bender et al. (eds.), and East Lansing: The African Studies Center, Michigan State University.

[12] Halle, Morris. 1989. The Intrinsic Structure of Speech Sounds. Ms., MIT, Cambridge, Mass.

[13] Heine, Bernd 1981.The Waata Dialect of Oromo. Grammatical Sketch and Vocabulary. Published as Volume of Language Berlin .

[14] Jeylan W. Hussien. (2005). "The Functions of African Oral Arts: The Arsi Oromo Oral Arts in Focus." In African Study Monographs, 26(1): 15-58, March

[15] Kebede Hordofa. (1991). "A Contribution to the Dialectology of Afaan Oromoo: Consonantal Suffix Conjugation after the Glides" In Proceedings of the 11th ICES (Addis Ababa 1991) Vol. I, pp. 501-513. Addis Ababa.

[16] Kebede Hordofa. (2005). "The Varieties of Oromo." ELRC, W Pap. AAU: AAU Printing Press. 1(1): 134-150

[17] Kebede, H. (2009). Towards the Genetic Classification of the Afaan Oromoo Dialects. Published PhD Thesis, Department of Linguistics and Scandinavian Studies: The University of Oslo, Norway.

[18] Lloret Romanyach, Maria-Rosa. (1994). "A Comparative Study of Consonant Assimilation in Some Oromo Dialects." Ms. A paper presented at the 3rd International Symposium on Cushitic and Omotic Languages, Berlin.

[19] McCarthy, John J. (1988). Feature geometry and Dependency: A Review, Phonetica 45: 84-108.

[20] Mindaye, Abebe 2005. The Oromo of Bale: A historical survey to 1974. Unpublished M.A. Thesis Addis Ababa University. Addis Ababa

[21] Sagey, Elizabeth (1986). The Representation of Features and Relations in Nonlinear Phonology. PhD dissertation, MIT. [published 1990 by Garland Press].

[22] Youssef, Islam. 2013. Place Assimilation; Contrasts, Features and Constraints. Ph.D. Thesis. University of Tromsø. 